\title{
The construction of undergraduate higher education quality evaluation system to promote the sustainable development of Higher Education
}

\author{
He JIANG ${ }^{1, a}$, Yonghui CAO ${ }^{* 2, b}$ \\ ${ }^{1}$ Department of Business Administration Guangzhou College of Technology and Business Guangzhou, China \\ ${ }^{2}$ Department of Business Administration Guangzhou College of Technology and Business Guangzhou, China
}

\begin{abstract}
The effective supply of higher education is important to cultivate innovative talents and improve the quality of higher education. In the new era, China's colleges and universities put forward to improve the quality of higher education as the goal, reasonable allocation of higher education supply resources and effectively promote the healthy development of higher education. Based on this, this paper takes the supply of higher education as the starting point, and constructs the evaluation index system of higher education supply based on the government, society and universities. It also improved the evaluation criteria for the school running standards, teaching quality, teaching staff and teaching achievements of higher education. So this paper has certain theoretical and practical significance to promote the effective supply of higher education and improve the quality of higher education supply.
\end{abstract}

\section{Introduction}

The 19th National Congress of the Communist Party of China proposed that high quality higher education is an important engine to realize national modernization and national rejuvenation. The effective supply of higher education is an important link to cultivate innovative talents and improve the quality of higher education. With the acceleration of the popularization of higher education, the development of higher education is very rapid, but there are also some drawbacks [1-3]. The outline of national medium and long term education reform and development plan (2010-2020) clearly points out that we should take improving the quality of higher education as the goal, rationally allocate the supply resources of higher education, and promote the healthy development of higher education. In particular, the document points out that we should establish and improve the evaluation index system of higher education, and improve the evaluation criteria for the school running standards, teaching quality, teachers and teaching achievements of higher education. This not only reflects that the country attaches great importance to higher education but also reflects the important significance of the construction of evaluation index system for higher education supply[4-6].

Higher education should improve the quality of personnel training, the level of scientific research and the ability of social service. At present, in the field of higher education in China, a large number of colleges and universities are expanding their enrollment. More and more attention has been paid to the quality evaluation of higher education. The quality evaluation of higher

aGZhappy2020@126.com

b*Corresponding author: Yonghui CAO: Xinrui20132015@126.com

education development has become the focus of research. The quality evaluation of higher education is an indispensable part in the research of higher education reform. The research on it is the rational attribution of the development of higher education in the global era. Even though the higher education evaluation has experienced many years of research and practice, and achieved results to a certain extent, there are still many problems worthy of further discussion and research [7]. In particular, it is beneficial to establish a relatively complete higher education quality evaluation system in line with the development trend of contemporary Chinese education. It can open up a new perspective and viewpoint for the quality evaluation of higher education in the new era of the 21 st century, which can be used to motivate and promote the improvement of the quality of higher education [8-9].

Based on this, this paper takes the supply of higher education as the starting point, constructs the evaluation index system of higher education supply based on the government, society and universities as the evaluation subjects, which has certain theoretical and practical significance to promote the effective supply of higher education and improve the quality of higher education supply in China.

\section{Analysis on the subject of higher education evaluation}

The evaluation of higher education can be divided into three parts: government evaluation, social evaluation and University self-evaluation. 


\section{1 government evaluation}

Government evaluation refers to the objective evaluation made by the government according to the overall goal and development direction of higher education, and provides targeted policies and suggestions for the development and construction of higher education according to the evaluation results, which is authoritative and mandatory. Government evaluation should be based on the idea of supervision and management of colleges and universities, aiming at promoting the management and construction of colleges and universities. At the same time, the government should publish the evaluation results in time as the basis of financial and policy support for colleges and universities. In China, government evaluation is the leading force to evaluate the development level of colleges and universities. The evaluation method, quality evaluation, evaluation team members, evaluation results and publication of higher education are all led by the government. This evaluation model greatly reduces the discourse power of colleges, enterprises and society in the evaluation of colleges and universities. At the same time, colleges and universities also lose some autonomy on whether to carry out external evaluation. Therefore, the government should change its functions, appropriately formulate the functional boundary of the government in higher education evaluation, prevent bureaucracy and formalism caused by excessive intervention, standardize and guide the identity of Higher Education Supervisor, and strengthen the objectivity and fairness of higher education evaluation sheet.

\subsection{Social evaluation}

With the popularization of higher education, social evaluation of higher education is more and more widely used. Social evaluation refers to the participation of social forces such as enterprise organizations, charities, industrial departments, academic groups and students' parents in the evaluation of higher education, which evaluates the quality of university graduates, social services and social influence, and timely feedback the evaluation results to ensure that the development of colleges and Universities is not divorced from the society. Social evaluation of higher education has the following characteristics: (1) Externality: the evaluation subject of social evaluation is the external personnel or organizations of colleges and universities; (2) Lag: the main aspect of social evaluation is the quality of college graduates, social services and influence of colleges and universities; (3) Collectivity: the collectivity of social evaluation is mainly reflected in that the evaluation object of higher education is not a specific student, but all the graduates of colleges and universities. The social evaluation of higher education plays an intermediary role between colleges and society. The objective evaluation and feedback of social evaluation on college graduates is conducive to the timely positioning of the deficiencies in education in Colleges and universities, so as to constantly adjust the structure and mode of teaching and accelerate the improvement of teaching quality.

\subsection{Self-evaluation of colleges and Universities}

Considering China's political system and social culture, the government's dominant position cannot be shaken in higher education, but it could decentralize part of its power and give space for self-evaluation of colleges and universities, so as to enhance the democracy and universality of higher education evaluation. The selfevaluation is to clearly evaluate the input, process and results of the internal infrastructure, network communication, scientific research environment, teaching quality and faculty in order to better carry out the teaching work and improve the teaching quality. Colleges and universities are not only the objects of higher education evaluation, but also the preconditions for external higher education evaluation. Therefore, higher education should abandon the psychological exclusion, actively play the main role, combined with external evaluation, and objectively evaluated their school running level and development limitations. The internal evaluation of colleges and universities emphasizes the evaluation of colleges and universities by all staff in Colleges and universities. The specific process includes the establishment of an internal evaluation team of colleges and universities, the employment of an external expert team, and the writing of the development of colleges and universities in advance. Through the mutual evaluation of colleges, students and teachers, it could compare the differences between the development goals and the actual situation, put forward improvement measures and implement deviation correction measures. At the same time, colleges and universities do not have the pressure of external evaluation in internal evaluation, so the evaluation results have certain objectivity.

\section{Evaluation model of Higher Education}

Undergraduate institutions can be divided into Researchoriented institutions, Application-oriented Institutions, comprehensive institutions, private institutions and independent institutions, which showing the characteristics of diversity and universality. A single evaluation model cannot meet the evaluation requirements of higher education. Therefore, the evaluation subject should adopt different evaluation models according to the development direction and training mode of colleges and universities. In addition to the traditional accreditation, audit and evaluation of higher education, we should also adopt research-oriented, comprehensive and applicationoriented talent training evaluation mode. The infrastructure and operation mode of research-oriented universities are relatively mature. Scientific research level and research results are important standards to measure the development of research-oriented universities. Therefore, teaching quality and students' quality should be the main assessment objects of research-oriented higher education training mode. Comprehensive higher education involves more comprehensive majors and pays more attention to students' all-round development. Therefore, diversified standards should be adopted to evaluate the training mode of comprehensive talents, so as 
to promote the comprehensive cultivation of students' moral, intellectual, physical, aesthetic and professional qualities. The application-oriented institutions should pay more attention to the cultivation of students' practical ability and vocational skills. Therefore, the evaluation of the application-oriented institutions should be led by enterprises and society, and the top-level design of school enterprise cooperation should be strengthened. At the same time, the education department should actively cooperate to ensure the realization of talents training objectives and the improvement of students' quality in Application-oriented Colleges and universities.

\section{Construction of higher education evaluation system}

\subsection{Principles for the construction of higher education evaluation system}

\section{First, the principle of goal orientation}

Goal orientation is to select the indicators that match the evaluation purpose and discard some indicators that are contrary to the evaluation objective. The principle of goal orientation enhances the objectivity and accuracy of index selection, which is an important factor in the selection of evaluation index. In addition, the establishment of evaluation goals can reduce the occurrence of incompatibility between indicators, and provide the development direction and forward goals for the supply of undergraduate colleges and universities.

Second, the principle of innovation

Higher education is the inexhaustible motive force of national innovation and development, and shoulders the important mission of cultivating innovative and applied talents. Therefore, the construction of higher education evaluation index system needs to consider the principle of innovation, keep pace with the times, set up innovative and dynamic evaluation index, creatively evaluate the education supply of undergraduate colleges and universities, and increase the vitality for the development

of undergraduate colleges and universities.

Third, the principle of integrity

As a system, the evaluation index system of colleges and universities should cover the basic contents of all aspects of higher education evaluation. The essence of the principle of integrity is to make each index cooperate with each other, achieve the expected goal of the whole, and reduce the one sidedness of index evaluation. Because of the dynamic and tedious characteristics of higher education, it does not violate the principle of integrity to abandon part of the indicators when setting up the evaluation index system. Integrity emphasizes the retention of those key indicators that can reflect the facts.

Fourth, the principle of development

Higher education is a social activity with the continuous development and progress of the times. The time dimension of higher education evaluation is relatively long. Therefore, the evaluation of higher education needs to adhere to the principle of development. Development principle is well known as dynamic principle, which refers to the periodic characteristics of an evaluation index system. The principle of development requires that when constructing the evaluation index system of higher education, we need to evaluate higher education dynamically based on the perspective of development and change.

Fifth, the principle of objectivity

The evaluation index system of higher education needs to have practical significance, which truly reflect the reality of higher education, and make the evaluation results fair and just. Based on the realization of the goal, the evaluation index reflects the objective essence of higher education. The objectivity of higher education evaluation index is also reflected in that the index system should avoid the setting of repeated indexes, that is, the indexes are independent of each other and do not contradict each other.

\subsection{Construction of higher education evaluation system}

Table 1 evaluation index system of Universities

\begin{tabular}{|c|c|c|}
\hline First level & Second level & Item \\
\hline \multirow{14}{*}{ background } & \multirow{3}{*}{$\begin{array}{l}\text { Source and scale } \\
\text { of students }\end{array}$} & Years of education per person \\
\hline & & Gross enrollment rate of higher education for the population aged 18-24 \\
\hline & & Number of college students per 100000 population \\
\hline & \multirow{2}{*}{$\begin{array}{l}\text { Academic } \\
\text { foundation }\end{array}$} & The books number of each student has \\
\hline & & Computer popularization rate of students in school \\
\hline & \multirow[t]{2}{*}{ School size } & Total building area of university buildings (10000 square meters) \\
\hline & & Value of teaching and scientific research instruments and equipment \\
\hline & \multirow{2}{*}{$\begin{array}{l}\text { Administrative } \\
\text { position }\end{array}$} & School orientation and its basis \\
\hline & & $\begin{array}{l}\text { The reflection of school running orientation in school development } \\
\text { planning }\end{array}$ \\
\hline & \multirow{2}{*}{$\begin{array}{l}\text { Training } \\
\text { objectives }\end{array}$} & The general goal of talent cultivation and its basis \\
\hline & & Professional training objectives, standards and determination basis \\
\hline & \multirow{3}{*}{$\begin{array}{l}\text { Position of talent } \\
\text { training center }\end{array}$} & $\begin{array}{l}\text { Policies and measures to implement the status of the school as a talent } \\
\text { training center }\end{array}$ \\
\hline & & The embodiment and effect of the position of talent training center \\
\hline & & Leaders' attention to undergraduate teaching \\
\hline & \multirow{3}{*}{$\begin{array}{l}\text { Investment in } \\
\text { Education }\end{array}$} & Proportion of higher education expenditure in GDP \\
\hline & & $\begin{array}{l}\text { Education expenditure per student (per student expenditure / per capita } \\
\text { GDP) }\end{array}$ \\
\hline & & Annual changes of teaching funds \\
\hline
\end{tabular}




\begin{tabular}{|c|c|c|}
\hline \multirow[t]{11}{*}{ input } & & Distribution, proportion and efficiency of teaching funds \\
\hline & & Financial aid for poor college students \\
\hline & \multirow{2}{*}{$\begin{array}{c}\text { Teaching } \\
\text { infrastructure }\end{array}$} & Laboratory and practice base \\
\hline & & Library situation \\
\hline & \multirow{2}{*}{$\begin{array}{l}\text { information } \\
\text { construction }\end{array}$} & Proportion of smart campus \\
\hline & & The construction of University Digital Library \\
\hline & \multirow{2}{*}{$\begin{array}{c}\text { Investment in } \\
\text { scientific research }\end{array}$} & Proportion of scientific research funds in GDP \\
\hline & & $\begin{array}{l}\text { The proportion of scientific research funds in the total scientific research } \\
\text { funds }\end{array}$ \\
\hline & \multirow[t]{3}{*}{ social resources } & Measures and effects of School-enterprise cooperation \\
\hline & & Co construction of teaching resources \\
\hline & & Social donations \\
\hline \multirow{20}{*}{ process } & \multirow{3}{*}{$\begin{array}{l}\text { classroom } \\
\text { teaching }\end{array}$} & Formulation and implementation of syllabus \\
\hline & & Methods and management of examination \\
\hline & & Construction and selection of teaching materials \\
\hline & Student engagement & Students' self-study time after class \\
\hline & \multirow[t]{2}{*}{ Practice Teaching } & Construction of practice teaching system \\
\hline & & $\begin{array}{c}\text { Implementation and effect of practical training, social practice and } \\
\text { graduation project (Thesis) }\end{array}$ \\
\hline & \multirow{6}{*}{ Teacher resources } & Proportion of teachers with doctoral degree \\
\hline & & Proportion of annual salary of teachers in per capita GDP \\
\hline & & Proportion of full-time teachers in all teaching staff \\
\hline & & Proportion of full-time teachers visiting for 3 months or more \\
\hline & & Policy measures to improve teachers' ability and professional level \\
\hline & & The construction plan and development trend of teaching staff \\
\hline & \multirow[t]{2}{*}{ Specialty setting } & Planning and implementation of specialty construction \\
\hline & & $\begin{array}{c}\text { Specialty setting and structure adjustment, advantage specialty and new } \\
\text { specialty construction }\end{array}$ \\
\hline & $\begin{array}{l}\text { Transformation of } \\
\text { teacher resources }\end{array}$ & Student teacher ratio \\
\hline & reform in & The general idea and policy measures of teaching reform \\
\hline & education & Training mode reform, personnel training system, mechanism reform \\
\hline & $\begin{array}{c}\text { Internationalizatio } \\
\mathrm{n}\end{array}$ & Number of Sino foreign cooperative education projects \\
\hline & Quality assurance & Construction of teaching quality assurance system \\
\hline & & quality improvement \\
\hline \multirow{20}{*}{ output } & \multirow{5}{*}{$\begin{array}{l}\text { Results of } \\
\text { personnel training }\end{array}$} & Proportion of major working age population with higher education \\
\hline & & $\begin{array}{l}\text { Composition of educational level of population in economic activities } \\
\text { (Higher Education) }\end{array}$ \\
\hline & & Social opening of educational resources \\
\hline & & Employment rate and career development of graduates \\
\hline & & Evaluation of graduates by employers \\
\hline & \multirow{5}{*}{$\begin{array}{l}\text { Scientific and } \\
\text { technological } \\
\text { achievements }\end{array}$} & Number of EI papers per teacher \\
\hline & & Number of SCI papers per teacher \\
\hline & & Publishing scientific and technological works \\
\hline & & Number of patent applications \\
\hline & & Conversion rate of applied R\&D achievements in Universities \\
\hline & \multirow{2}{*}{$\begin{array}{l}\text { academic } \\
\text { exchange }\end{array}$} & Number of international academic conferences \\
\hline & & Number of participants in international academic exchanges \\
\hline & \multirow{3}{*}{$\begin{array}{l}\text { Discipline } \\
\text { construction }\end{array}$} & Number / proportion of national key disciplines \\
\hline & & Academic leaders at all levels \\
\hline & & National and regional plans to train scholars \\
\hline & \multirow{3}{*}{ Social services } & Average annual number of non-academic education in Universities \\
\hline & & Average ratio of technology and patent transfer per teacher \\
\hline & & Number of industry university research cooperation \\
\hline & \multirow{2}{*}{$\begin{array}{l}\text { International } \\
\text { influence }\end{array}$} & Proportion of international students in the world \\
\hline & & World academic rankings of Shanghai Jiaotong University \\
\hline
\end{tabular}




\section{Conclusion}

To sum up, colleges and universities in China are promoting the development of higher education by reasonably allocating the supply resources of higher education in order to improve the quality of higher education. This paper establishes the evaluation index system of higher education, which improves the evaluation criteria of school running standards, teaching quality, teachers and teaching achievements of higher education. The evaluation index system of higher education is based on the government, society and universities. It has certain theoretical and practical significance for promoting the effective supply of higher education and improving the quality of higher education.

\section{Acknowledgment}

This work is financially supported by outstanding scholars of philosophy and Social Sciences in Henan Province higher education in 2018, 2018-YXXZ-06; Henan philosophy and Social Sciences Planning Project in 2019, 2019BJJ003; The social development project of Henan provincial key R \& D and promotion project (Science and technology tackling key problems) in 2019, project number: 515; Intellectual property soft science research project of Henan Province in 2021, 20210106014; Guangdong Education Science Planning Project, building an efficient and intelligent supply chain system to promote the high-quality economic development of GuangdongHong Kong-Macao Greater Bay Area, 2019GXJK072; Henan philosophy and Social Sciences Planning Project in 2019, 2019BJJ032; Key scientific and technological projects of Henan Province in 2021, 212102310051, Research on emergency decision-making mechanism and key technologies of major public emergencies; the key scientific research project of colleges and universities in Henan Province in 2021, 21A620002; General Topics of Henan Province Educational Science "13th Five-Year Plan" in 2020, Research on the dynamic mechanism of the integration of industry and education in Henan Province, 2020YB0146; Guangdong higher education reform project in 2020, No. 642, innovative research and practice of logistics personnel training mode based on new information technology under the background of new business. The project of quality engineering of Guangzhou College of Technology and Business in 2020, serial number 25 , the exploration of the dynamic mechanism and path of the integration of production and education of undergraduate colleges in Guangdong-Hong Kong-Macao Greater Bay Area. Thanks for the help.

\section{References}

1. Hu Bicheng, Li Bin. On the market mechanism of higher education quality regulation [J]. Higher education research, 2014,35 (07): 26-33

2. Fang Linyou, Zhang chuting. Subject identity, government role and intermediary organization status:
A Study on China's higher education market mechanism [J]. Higher education research, 2014,35 (11): 76

3. Guo Peipei. Research on the construction of evaluation index system of higher education modernization in Zhejiang Province [D]. Hangzhou Normal University, 2018

4. Zhou Zhengxu, Zeng Lijing. Research on the construction of evaluation index system of internal control construction in Colleges and universities [J]. Modern business, 2018, (22): 120-121

5. Wang Ning. Research on the quality evaluation index system of China's general higher education [J]. Education modernization, 2017,4 (18): 62-67

6. Geng Guiying. Research on higher education evaluation in China [D]. Nanjing University of Aeronautics and Astronautics, 2012

7. Li Yi, Xiang Hao. Research on the construction of classroom teaching quality evaluation system in Colleges and universities [J]. China Hi tech, 2019, (08): 30-33

8. Li Hua. Construction of quality evaluation system under the background of popularization of Higher Education [J]. Journal of Chongqing University of science and Technology (SOCIAL SCIENCE EDITION), 2015, (05): 97-99 + 102

9. Li Dan. Construction of undergraduate teaching quality evaluation system under the guidance of Applied Talents Training [J]. Quality education in Western China, 2019,5 (06): 150-151. 